\title{
Leksikon YU mitologije - fenomeny jugosłowiańskiej kultury popularnej i ich „życie po życiu”
}

Jugosłowiańska kultura popularna od jakiegoś już czasu coraz bardziej interesuje Polaków i w ślad za tym zyskuje w Polsce miłośników, a nawet znawców. Wiąże się to niewątpliwie z rozwojem studiów na kierunkach takich, jak filologia (południowo)słowiańska, filologia bałkańska czy bałkanistyka, a także z coraz częstszym podejmowaniem przez historyków, antropologów kultury, literaturoznawców, etnologów i - co godne podkreślenia - również przez politologów badań nad przeszłością i współczesnością obszaru postjugosłowiańskiego, w których eksplikowane są różne zagadnienia kulturalne, społeczne i polityczne.

Wyjątkowym dziełem w zakresie skatalogowania i rozpoznania fenomenów kultury popularnej komunistycznej Jugosławii jest Leksikon YU mitologije, ogłoszony drukiem po raz ostatni w 2005 roku w Serbii, we współpracy belgradzkiego wydawnictwa Rende z chorwackim (zagrzebskim) domem wydawniczym Postscriptum i kolportowany głównie w Serbii i Czarnogórze oraz w Chorwacji, jak również - w wyraźnie mniejszym zakresie - w innych państwach postjugosłowiańskich ${ }^{1}$. Ta imponująca księga, zredagowana przez Irisa Adricia,

* Doktor, Komisja Bałkanistyki Polskiej Akademii Nauk/Oddział w Poznaniu.

1 I. Adrić, V. Arsenijević, Đ. Matić (red.), Leksikon YU mitologije, Beograd 2005. Wydanie pierwsze: Beograd-Zagreb 2004. Na stronie internetowej: http://leksikon-yu-mitologije.net/autori/ [dostęp: 12.07.2013] podana została lista osób, które wespół 
Vladimira Arsenijevicia i Đorđe Maticia w kilkanaście lat po rozpadzie Socjalistycznej Federacyjnej Republiki Jugosławii (SFRJ), stanowi rezultat pracy wielu profesjonalnych leksykografów oraz jeszcze większej grupy leksykografów-amatorów, reprezentujących różne narodowości ${ }^{2}$ Jest to także, co zasługuje na podkreślenie, realizacja zamysłu twórczego Dejana Kršicia i Ivana Moleka (redaktorów zagrzebskiego czasopisma „Start”) ${ }^{3}$ oraz - znanej polskim czytelnikom lepiej - Dubravki Ugrešić ${ }^{4}$, wysuniętego przez tych ludzi pióra w 1989 roku (a więc wówczas, gdy SFRJ przeżywała już poważny kryzys wewnętrzny, niosący realną groźbę rozpadu państwa), następnie zaś ożywionego przez I. Adricia i Đ. Maticia w drugiej połowie lat 90. XX wieku, po spotkaniu wymienionych z D. Ugrešićs .

Leksikon YU mitologije, wydawany dwukrotnie w tradycyjnej papierowej wersji, znany również dzięki edycjom w Internecie, stał się bestsellerem. Jednocześnie doczekał się on wykorzystywania dla celów dydaktycznych i badawczych przez przedstawicieli różnych dyscyplin naukowych podejmujących problematykę jugosłowiańską, a także poświęcanych mu studiów ${ }^{6}$. Autorzy piszący dotychczas o tej publikacji analizowali jej treść, wykorzystany na kartach

z I. Adriciem, V. Arsenijeviciem oraz Đ. Maticiem współtworzyły publikację w 2004 r. (redaktorzy odpowiadający za graficzną stronę publikacji, pomocnicy redaktorów, korektorzy z Belgradu i Zagrzebia). W tym samym miejscu zamieszczono informację o dwóch internetowych wydaniach leksykonu: tworzonym w latach 2001-2011 w Arkzinie (www.arkzin.net) przez Blaženko Karešina i Marko Vukovicia, a także redagowanym na stronach zagrzebskiego wydawnictwa Postscriptum (www.postscriptum.hr) przez Željko Serdarovicia, przy współpracy: Zorana Stošicia, Željko Luketicia, Mladena Đikicia, Slađany Novaković i Brigity Međo. Na głównej stronie wydawnictwa Postscriptum i jej kilku podstronach podawane są również liczne informacje nt. Leksikonu i jego recepcji. Informacje o publikacji (w mniejszej ilości) wraz z wyimkami z niej podaje również główna strona wydawnictwa Rende (www.rende.rs) oraz, w ramach projektu Edicija ledolomac, jej podstrona http://www.rende.rs/modules.php?op= modload\&name $=$ News\&file $=$ article\&sid $=138$ [dostęp: 13.07.2013]. W niniejszym artykule źródło cytowań (skrót: LYUM) i innych odwołań, w których sięga się wprost do treści Leksikonu, stanowi wydanie z 2005 roku.

2 A. Radak, Od Adrije pa do žmurke, „Zarez. Dvotjednik za društvena i kulturna zbivanja” 2004, nr 132, s. 13.

3 I. Adrić, The Lexicon of Yu-Mythology: 1989-2001, „Newsletter” 2001, no. 9, http:// www.ceebp.org/Nwslet9June2001.htm [dostęp: 13.07.2013].

4 Jeden z dostępnych w Internecie biogramów D. Ugrešić, zawierający wykaz jej książek wydanych w Polsce: http://czarne.com.pl/katalog/autorzy/dubravka-ugresic [dostęp: 13.07.2013].

5 I. Adrić, Đ. Matić, [Wprowadzenie], [w:] LYUM, s. 4.

6 http://leksikon-yu-mitologije.net/ [dostęp: 12.07.2013]. 
publikacji design $^{7}$, a także nadzwyczajną rolę, odegraną przez Leksikon w pewnych środowiskach, nie wyłączając przypisywanego mu znaczenia dla procesów wzajemnego poznawania i rozumienia, a nawet jednania się przedstawicieli różnych narodów byłej Jugosławii, skonfliktowanych przez dramatyczny rozpad scalającego ich wcześniej federacyjnego państwa ${ }^{8}$.

Poniżej znajdą się nawiązania do wskazanych tu kwestii. Przedstawiane przemyślenia, dotyczące niektórych, wybranych dla celów egzemplifikacyjnych, treści umieszczonych w Leksikonie, mają jednak nie tylko stanowić okazję do zaprezentowania wybranych artefaktów związanych z okresem istnienia komunistycznego państwa jugosłowiańskiego, skądinąd zresztą ciekawych, czy też - tym bardziej - do ustalania w ślad za innymi badaczami tego, jaka była skala zainteresowania dziełem wśród „jugosłowiańskich” czytelników oraz na ile jego lektura dopomogła im lepiej zrozumieć wspólną jugosłowiańską przeszłość i niewywodzącą się z tego samego narodu resztę Jugosłowian. Ma to być przede wszystkim, choćby zupełnie skromny, przyczynek do refleksji i dyskusji nad związkiem fenomenów jugosłowiańskiej kultury popularnej z tożsamością Jugosłowian, jak również nad ich obecnym funkcjonowaniem (a więc

Zob. http://postscriptum.hr/leksikon-yu-mitologije [dostęp: 12.07.2013].

8 Zob. A. Bošković, Yugonostalgia and Yugoslav Cultural Memory: Lexicon of Yu Mythology, ,Slavic Review. Interdisciplinary Quarterly of Russian, Eurasian, and East European Studies" 2008, no. 1, http://www.slavicreview.illinois.edu/indexes/vol72/721.html\#boskovic [dostęp: 12.07.2013]; I. Adrić, op. cit.; I. Pauker, Reconciliation and Popular Culture: A Promising Development in Former Yugoslavia?, ,Local-Global: Identity, Security, Community" 2006, no. 2, s. 72-81, http://mams.rmit.edu.au/wcch64c2r40r.pdf [dostęp: 13.07.2013]; R. Dragojević, Ironija kao znak nemoći, „Novosti” 2013, nr 681; Ko je dobro, a ko loše prošao u Jugoslaviji (rozmowa O. Karabega z M. Dragičević-Šešić i I. Žaniciem, 7.10.2012), http://www.slobodnaevropa.org/content/most-ko-je-dobro-a-ko -lose-prosao-u-jugoslaviji/24731248.html [dostęp: 13.07.2013]; S. Kostić, L. Cvetković, U traganju za izgubljenim identitetima, „Zarez. Dvotjednik za društvena i kulturna zbivanja" 2004, nr 132, s. 12-13; A. Radak, op. cit., s. 13; P. Jurčević, 'Leksikon YU mitologije' u Puli, hrvatskom gradu u kojemu je Thompsonu zabrjen nastup, http://www.hrsvijet. net/index.php?option=com_content\&view_article\&id=18584:leksikon-yu-mitologije-u-puli-hrvatskom-gradu-u-kojem-jethompsonu-zabranjen-nastup\&catid=47:kazaliste\&cI temid=162 [dostęp: 13.07.2013]; www.postscriptum.hr [dostęp: 12.07.2013]; http://postscriptum.hr/leksikon-yu-mitologije [dostęp: 12.07.2013]; http://leksikon-yumitologije.net/; http://inanutshell.hr/ [dostęp: 13.07.2013]; https://twitter.com/Leksikon YU [dostęp: 13.07.2013]; https:/www.facebook.com/pages/Leksikon-YU-mitologije/ 237166539751167 [dostęp: 13.07.2013]; http://www.youtube.com/leksikonyumitologije [dostęp: 13.07.2013]; http://postyu.info/ [dostęp: 12.07.2013]; M. Rekść, Jugonostalgia i titonostalgia. Tęsknota za przeszłościa w wyobrażeniach zbiorowych społeczeństw byłej Jugosławii, [w:] Poznać Bałkany. Historia - polityka - kultura - języki IV, K. Taczyńska, A. Twardowska (red.), Toruń 2012, s. 241. 
i ,życiem po życiu”); wreszcie - nad uwarunkowaniami procesu powstawania niektórych, specyficznych obrazów pamięci zbiorowej, wśród których w odniesieniu do obszaru postjugosłowiańskiego na pierwszym planie należy dostrzec jugonostalgię ${ }^{9}$, stanowiącą zresztą jeden $\mathrm{z}$ istotniejszych imperatywów uczestnictwa wielu spośród autorów Leksikonu w jego tworzeniu.

Nawiązując do tego, co już zasygnalizowano, warto dostrzec, że u genezy Leksikonu YU mitologije znalazła się pewna konstatacja, sformułowana przez pomysłodawców tego dzieła, będąca ich diagnozą ,,jugosłowiańskości”. Jak ujęli to I. Adrić i Đ. Matić, wymieniana wyżej trójka twórców inicjująca komponowanie Leksikonu (Kršić, Molek, Ugrešić), doszła do wniosku, iż, po dziesięcioleciach funkcjonowania państwowej, a więc poniekąd i kulturowej, wspólnoty jugosłowiańskiej, nie istnieje coś takiego, jak wyartykułowane pojęcia jugosłowiańskiej kultury popularnej, które byłyby pomocne w definiowaniu tożsamości jugosłowiańskiej (czy też - „tożsamości jugosłowiańskich”) ${ }^{10}$. Konstatacji niniejszej towarzyszyło silne przeświadczenie istnienia takiej sytuacji politycznej, takiego napięcia w SFRJ, które za chwilę doprowadzi do przełomu w relacjach wewnątrzjugosłowiańskich, $\mathrm{z}$ nieuniknionym skutkiem odejścia do lamusa stworzonej w Jugosławii rzeczywistości kulturowo-społecznej.

$\mathrm{W}$ takim momencie, pojawienie się charakterystycznych pytań o to, „kim byliśmy?” i „kim jesteśmy?” oraz głosu, stanowiącego apel o zbadanie i udokumentowanie, w celu ocalenia przed zapomnieniem, poszczególnych komponentów „jugosłowiańskości” (zarówno jej istotniejszych elementów, np. mitów, z których usiłowano tworzyć tożsamość multietnicznego społeczeństwa, jak i całej drobnicy fenomenów, naznaczających przestrzeń życia codziennego Jugosłowian od północnosłoweńskich Jesenic do południowomacedońskiej Gevgeliji), powinno wydawać się czymś zupełnie naturalnym. Może się ono jawić nawet jako coś, co jest $\mathrm{z}$ rozmaitych względów potrzebne - i to nie tylko grupce intelektualistów, przejętych zmieniającą się codziennością, ale też masom. Zdaje się, że I. Adrić i Đ. Matić, decydując się na zrealizowanie dzieła, którego idea i ramy zakreślone zostały ostatecznie przede wszystkim przez znaną z postawy nonkonformistycznej i obnażania „kultury kłamstwa”

9 Udana definicja pojęcia jugonostalgia: M. Bogusławska, Jugonostalgia, [w:] Popkomunizm. Doświadczenie komunizmu a kultura popularna, M. Bogusławska, Z. Grębecka (red.), Kraków 2010, s. 351-353. Zob. też: M. Rekść, op. cit., s. 233-256; A. Bošković, op. cit.; I. Pauker, op. cit., s. 77-79 (w tekście niniejszym odwołania do teorii Erica Gordy’ego, a także do ujęć V. Tucana i D. Katilovicia oraz definicji „nostalgii” M. Janovera przedstawionej w: M. Janover, Nostalgias, „Critical Horizons” 2001, no. 4, s. 115).

10 W oryginale: krenulo se od premise da ne postoje artikularni pojmovi jugoslovenske popularne kulture koji bi pripomogli definiranju naših identiteta - I. Adrić, Đ. Matić, op. cit., s. 4 [wszystkie tłumaczenia w tekście pochodzą od autora]. 
D. Ugrešić, nie tylko sami odczuwali potrzebę zmierzenia się z dziedzictwem kulturowym wynoszonym z czasów jugosłowiańskich, nie odrzucając a priori możliwości dopuszczenia w jego opisie tak krytyki, jak i afirmacji jako tonów równouprawnionych, ale też z ironicznym dystansem oceniali tych wszystkich, którzy chcieliby $\mathrm{w}$ nowo powstających państwach wyrzucić jugosłowiańską przeszłość na śmietnik historii. W słowie wstępnym do Leksikonu zaznaczone zostało to wyraźnie:

[...] dziś brzmi to ironicznie - od pytania „kim jesteśmy?”, doszliśmy do [pytania] „kim byliśmy?”, a dla wielu i ta kwestia stała się „zbyteczną”, gdyż odpowiedź była im już z góry „znana”. Nowe państwa różnie odniosły się do przeszłości i do kwestii pamięci (wspomnień) - od konfiskaty pamięci i reinterpretacji przeszłości, aż po absolutne jej odrzucenie (zanegowanie) i [wprowadzenie] nowej rachuby czasu [od] swoistego „roku zero"11.

Choć jugosłowiańska przestrzeń społeczno-polityczna okresu komunistycznego charakteryzowana może być wymownie - by sięgnąć tu znów do pojęć stosowanych przez D. Ugrešić - jako „kultura kłamstwa”' ${ }^{2}$, na rozpad Jugosławii spoglądać można jednak, za przywołaną tu chorwacką pisarką, przede wszystkim jako na erozję dotychczasowych wartości, stanowiących długotrwałą treść życia całych społeczności ${ }^{13}$. Proces tego rodzaju, w swojej naturze niezwykle złożony, pozwala zredefiniować ogląd przeszłości. Niesie on w sobie potencjał, który uczestniczące w nim jednostki i grupy społeczne wykorzystać mogą zarówno do demitologizacji, jak i (re)mitologizacji konkretnych fenomenów rzeczywistości minionej, co waży na tym, jakie jej obrazy pozostają w pamięci zbiorowej jako bardziej lub mniej nośne (w większym bądź $\mathrm{w}$ mniejszym stopniu wpływające na formułowany $\mathrm{w}$ przestrzeni publicznej przekaz na temat historii). Zauważyć w tym miejscu warto, iż jest rzeczą wręcz charakterystyczną, że społeczności konfrontujące się z procesem erozji idei, przez długi czas uznawanych za aksjologiczną podstawę własnej egzystencji, dokonując fundamentalnych przewartościowań w jakiejś mierze wbrew sobie (będąc zobligowanym do konwersji z zewnątrz), odznaczają się skłonnością do

11 W oryginale: „[...] danas zvuči ironično. Od pitanja 'što smo?', došlo se do ‘̌to smo bili?', a mnogima je i to pitanje postalo 'suvišno', jer im je odgovor unaprijed bio 'poznat'. Nove su se države različito odredile prema prošlosti i sjećanju - od konfiskacije pamćenja i reinterpretacije prošlosti do apsolutnog negiranja i novog brojanja vremena, neke vrste 'godine nulte"' - I. Adrić, Đ. Matić, [w:] LYUM, s. 4.

12 D. Ugrešić, Kultura kłamstwa, Wołowiec 2006.

13 Zob. B. Czapik-Lityńska, Rozpad Jugosławii jako rozpad wartości. Punkt widzenia Dubravki Ugrešić i Slavenki Drakulić, „Południowosłowiańskie Zeszyty Naukowe” 2007, nr 4, s. 31; M. Rekść, Bałkańskie trawestacje mitu pochodzenia, „The Peculiarity of Man” 2010, nr 14, s. 242. 
kreowania „nostalgicznych opowieści, opartych na archetypie raju utraconego", gdzie idealizowana wspólnotowość z jej tradycyjnymi wartościami przedstawiana będzie jako wzorzec ${ }^{14}$.

Do pewnego stopnia w konwencję tego rodzaju kreacji wpisać można również przypadek postjugosłowiańskiego projektu zestawienia w postaci leksykonu fenomenów popkultury tworzących przestrzeń „yu-mitologii”. Leksikon YU mitologije stanowi wszakże oryginalny zapis jugosłowiańskiej przeszłości, będący w gruncie rzeczy niespójną (wpłynąć musiało na to szerokie grono twórców dzieła i wielość przyjmowanych przez nich perspektyw badawczych oraz założeń ideowych), paraencyklopedyczną narracją o tym, czym mieszkańcy republik jugosłowiańskich żyli w czasie, gdy tworzyły one jedną federacyjną, urządzoną w specyficzny sposób (ideologiczna i ekonomiczna oryginalność jugosłowiańskiego modelu socjalizmu) strukturę państwową, co ich scalało, co stanowiło najgorętsze ze wspólnotowo przeżywanych emocji. Być może faktycznie wśród pojęć jugosłowiańskiej kultury popularnej brakło takich, które uznać można by za kluczowe dla zdefiniowania/opisania tożsamości obywateli SFRJ, choć z pewnością można by spróbować wyselekcjonować kilka posiadających walory predestynujące je do tej roli; być może istotnie jugosłowiańską kulturę popularną charakteryzował chaos, pozornie tylko organizowany przez ogólnopaństwowe symbole oraz idee, których emitentem było polityczne centrum - jednakże ów galimatias w Leksikonie I. Adricia, V. Arsenijevicia i Đ. Maticia został w jakiś przedziwny sposób uporządkowany, mimo demonstracyjnej wręcz niejednorodności dzieła (przejawiającej się nawet pod względem językowym - oprócz haseł napisanych w językach serbskim i chorwackim czy też w standardzie, który określano przez dziesięciolecia mianem języka serbskochorwackiego, w Leksikonie występuje nieco haseł w językach macedońskim i słoweńskim). W efekcie eklektyczny (jednak nie męczący odbiorcy swymi nierównościami) Leksikon pełnić może też funkcje przewodnika po rozmaitościach jugosłowiańskiej popkultury, swoistego wprowadzenia w jugosłowiańskość w jej różnych odsłonach (kult Tity, idee braterstwa i jedności narodów SFRJ oraz samorządności z jednej; sport, muzyka, nocne życie, tatuaże, užički kajmak z drugiej strony).

Zestaw pojęć, którym zdecydowano się dać miejsce w Leksikonie imponuje. Sam indeks osób wymienianych w tej publikacji (nie wszystkim jednak poświęcono oddzielne hasła) zajmuje aż 16 stron $^{15}$. Jak już wspomniano, hasła opracowało wielu autorów, z których część (zapewne rekrutująca się głównie z grona osób nieparających się profesjonalnie pisaniem tego typu tekstów) nie zdecydowała się na podawanie swoich personaliów. Lektura Leksikonu pozwala dostrzec,

\footnotetext{
14 M. Rekść, Konsumpcjonizm w wydaniu albańskim, „The Peculiarity of Man” 2012, nr 15, s. 204.

15 LYUM, s. 446-461.
} 
że często już za samym uznaniem danego hasła przez jego autora na zasługujące na zamieszczenie w książce, a następnie za wyborem konwencji, w której zostało ono opracowane i zaprezentowane (dobór objaśniającego daną kwestię słownictwa, względnie dodatkowo wskazane ukontekstowienie), stały przeróżne motywacje, osobiste oceny opisywanej/go: osoby/rzeczy/idei/zjawiska/ wydarzenia etc., a także określony stosunek żywiony do jugosłowiańskiej przeszłości jako takiej. Stąd na kartach Leksikonu ujawniona została cała gama postaw jego twórców względem „nieboszczki Jugosławii” - od entuzjazmu, aż po bezlitosny krytycyzm, z dominantą nostalgii. Ta ostatnia okazała się notabene wspólna i dla tych, którzy autentycznie tęsknią za jugosłowiańskim modelem socjalizmu oraz ideami krzewionymi w samej SFRJ i przez nią na forum międzynarodowym, i dla tych, którzy mimo antysocjalistycznych i antyfederacyjnych przekonań, z rozrzewnieniem myślą o czasie swojej młodości, dla której okrasę stanowily letnie wojaże nad Adriatyk wysłużoną Zastavą ${ }^{16}$ czy też świętowanie w gronie przyjaciół sukcesów jugosłowiańskich sportowców (szczególnie: koszykarzy, futbolistów, waterpolistów) ${ }^{17}$, tudzież udział w prywatkach, podczas których słuchano przebojów wylansowanych przez Bijelo dugme ${ }^{18}$ lub Zdravka Ćolicia ${ }^{19}$.

Nadzwyczajna „pojemność” Leksikonu, w którym zamieszczono hasła wiążące się z różnorodnymi aspektami i zjawiskami jugosłowiańskiego życia, pokazuje pełną paletę jego barw. Jest w tym niebanalnym dziele tak powaga, jak i śmieszność byłej Jugosławii i jej realiów, szczególnie tych, które kształtowały jugosłowiańską kulturę popularną. Jest bałagan i swoisty ład zarazem. Jest tak fantastycznie szeroka dokumentacja pełnej kontrastów jugosłowiańskiej rzeczywistości minionej, że - jak trafnie ujęto to w jednym $\mathrm{z}$ artykułów poświęconych temu dziełu - stanowi ono fenomen sam w sobie ${ }^{20}$.

16 Zob. D. Novačić, Fića, [w:] LYUM, s. 137; M. Tasić, B. Popović, anonim, Yugo, [w:] LYUM, s. 424-426. Temat Zastavy (kultowego modelu 750, zwanego ficia) w interesujący sposób podjęto również na gruncie polskim: K. Binda, Zastawa 750 po Jugosławii, [w:] M. Bogusławska, Z. Grębecka (red.), op. cit., s. 271-286.

17 W Leksikonie zawarte zostało relatywnie dużo haseł dotyczących asów jugosłowiańskiego sportu (gwiazd dyscyplin indywidualnych i drużyn), a także konkretnych wydarzeń sportowych. Zredagowano je w większości w duchu entuzjazmu dla dawnych mistrzów, ogólnojugosłowiańskiej dumy z sukcesów odnoszonych przez reprezentantów całego państwa oraz łatwo dającej się dostrzec nostalgii. W ocenie piszącego te słowa, a także we współczesnych, postjugosłowiańskich realiach, tematyka sportowa odgrywa szczególnie doniosłą rolę w dyskursie publicznym. Uwagę niniejszą odnieść można właściwie do całego obszaru byłej SFRJ.

18 Zob. B. Rosić, Kad bi bio Bijelo dugme, [w:] LYUM, s. 178-181. Zob. również: I. Pauker, op. cit., s. 75-77.

19 Zob. B. Rosić, M. Babić, Ćolić, Zdravko, [w:] LYUM, s. 78.

20 Fenomen Leksikon, http://leksikon-yu-mitologije.net/. 
Na kartach Leksykonu spotykają się ze sobą marszałek Josip Broz Tito (nie tylko $\mathrm{w}$ poważnej pozie $\mathrm{z}$ globusem $\mathrm{w}$ dłoniach ${ }^{21}$, ale i w prześmiewczym haśle-biogramie ${ }^{22}$, jak również w osobnych fragmentach poświęconych m.in. jego śmierci ${ }^{23}$, mowom ${ }^{24}$, inspirowanym jego postacią turniejach szkolnych ${ }^{25}$, powiedzonku Tito, potem Bóg ${ }^{26}$, czy też spektakularnym formom manifestowania w 1981 roku pamięci o zmarłym rok wcześniej przywódcy ${ }^{27}$ ), jego żona Jovanka Broz (Budisavljević) ${ }^{28}$, jeden z ważniejszych liderów politycznych jugosłowiańskiego państwa (do 1966 roku) Aleksandar Ranković (1909-1983) ${ }^{29}$, ale także nieco zapomniany przewodniczący prezydencji SFRJ w 1983 roku Mika Špiljak (1916-2007) ${ }^{30}$ czy też, jeszcze bardziej zapomniana, premier SFRJ z lat 1982-1986 Milka Planinc (1924-2010) ${ }^{31}$. O dziwo, brak w Leksikonie osobnego hasła poświęconego Milovanovi Đilasovi (1911-1995), choć ten najbardziej znany jugosłowiański dysydent, pojawia się wielekroć wzmiankowany $\mathrm{w}$ innych hasłach ${ }^{32}$.

${ }^{21}$ LYUM, s. 397.

22 D. Novačić, Tito, [w:] LYUM, s. 396.

23 LYUM, s. 398-401.

24 M. Marković, D. Kršić, B. Lenarčić, Titovi govori, [w:] LYUM, s. 396.

25 J. Baljak, Tito-revolucija-mir, [w:] LYUM, s. 396. Obok współzawodnictwa uczniów i szkół w ramach wskazanego turnieju, na który składały się dwa etapy (pierwszym było rozwiązywanie zagadek z czasopisma „Kekec” związane z rywalizacją na szczeblach szkolnym, gminnym, miejskim, republikańskim i centralnym; drugim - finałowa rozgrywka organizowana dla najlepszych we wcześniejszym etapie reprezentantów z całego państwa), warto pamiętać również o organizowaniu innych wydarzeń, przez które młodzież czciła jugosłowiańskiego wodza, np. biegów sztafetowych dla uhonorowania kolejnych rocznic narodzin przywódcy, organizowanych nawet jeszcze po śmierci J. Broza Tity. Szerzej na temat tego i innych zabiegów kształtujących kult marszałka i prezydenta SFRJ: L. Radenković, Tito jako bohater mityczny, [w:] Komunistyczni bohaterowie, t. 1: Tradycja, kult, rytuat, M. Bogusławska, Z. Grębecka, E. Wróblewska-Trochimiuk (red.), Warszawa-Kraków 2011, s. 125-138. Zob. też: M. Bogusławska, Być jak Josip Broz! Komunistyczny projekt dzieciństwa - przypadek jugosłowiański, [w:] Komunistyczni bohaterowie, t. 2: Przemiana, bunt, odrzucenie, M. Bogusławska, Z. Grębecka (red.), Warszawa-Kraków 2012, s. 13-33.

26 V. Ognjenović, Tito pa Bog, [w:] LYUM, s. 396, 402.

27 T. Grubar, A. Božičević, Osamdesatosam ruža za druga Tita, [w:] LYUM, s. 287.

28 Đ. Matić, Broz, Jovanka, [w:] LYUM, s. 61.

29 V. Sekulić, Ranković, Aleksandar, [w:] LYUM, s. 333.

30 Đ. Matić, Śpiljak, Mika, [w:] LYUM, s. 383.

31 S. Antolić, Planinc, Milka, [w:] LYUM, s. 310.

32 LYUM, s. 22, 206, 244, 296, 333, 349, 396. Ostatnio szerzej na temat tej postaci w Polsce: H. Stys, Inna twarz totalitaryzmu. III Plenum KC Związku Komunistów Jugosławii (1617 stycznia 1954) i odsunięcie Milovana Đilasa od władzy, „Dzieje Najnowsze” 2009, nr 2, s. 57-93; idem, Milovan Đilas o wodzach rewolucji, „Dialog i Polityka” 2008, nr 10, 
Wymienionym politykom (i innym, niewymienionym tu) towarzystwa w Leksikonie dotrzymują ważne dla jugosłowiańskiej kultury postaci, jak pisarz Miroslav Krleža ${ }^{33}$ czy pianista Ivo Pogorelić ${ }^{34}$, ale także: kultowy aktor Bata Živojinović $^{35}$, dziennikarz-celebryta Miroslav Lazanski ${ }^{36}$ oraz, egzemplifikujący tu licznie przedstawiane w Leksikonie gwiazdy jugosłowiańskiego sportu i rozrywkowej sceny muzycznej, bokser Marijan Beneš ${ }^{37}$ czy piosenkarka Fahreta Jahić, występująca pod pseudonimem Lepa Brena ${ }^{38}$.

Bez trudu zauważyć można, iż redaktorom Leksikonu, włączającym doń hasła otrzymane od różnych autorów (czasem - jak już wspomniano - anonimowych), bliska była idea pokazania, że zarówno kulturę popularną „na żywo", jak i jej późniejszy obraz, tworzą, niekoniecznie intencjonalnie, lecz jednak w gruncie rzeczy w podobnej mierze, nie tylko zawodowi dostarczyciele rozrywki i twórcy wszelakiego, adresowanego do mas, przekazu medialnego o charakterze kulturalnym, ale także - również zaklasyfikowani przez społeczeństwo do kategorii „bohaterowie popkultury” - politycy, twórcy kultury wysokiej (i ich, żyjące swoim życiem, dzieła ${ }^{39}$ ), czy nawet ludzie instytucjonalnej nauki ${ }^{40}$.

s. 97-113; idem, Dysydenci i opozycja w socjalistycznej Jugosławii 1945-1990. Wybrane zagadnienia, [w:] Poznać Bałkany. Historia - polityka - kultura, K. Taczyńska, S. Sochacki, M. Zečević (red.), Toruń 2011, s. 65-84; idem, Milovan Djilas i Polska - wzajemne inspiracje, [w:] Poznać Bałkany. Historia - polityka - kultura - języki V, K. Taczyńska, A. Twardowska (red.), Toruń 2013, s. 79-105.

33 F. Poljički, Krleža, Miroslav, [w:] LYUM, s. 205-207.

34 Đ. Matić, Pogorelić, Ivo, [w:] LYUM, s. 314.

35 NoMad, Filmska banka, Živojinović, Velimir Bata, [w:] LYUM, s. 441-442.

36 T. Gruber, anonim, Lazanski, Miroslav, [w:] LYUM, s. 220.

37 B. Rosić, Beneš, Marijan, [w:] LYUM, s. 46-47.

38 Đ. Matić, Lepa Brena, [w:] LYUM, s. 223-226.

${ }^{39}$ Np. wydarzenia kulturalne czy tytuły prasowe. Zob. hasła: D. Kršíć, BITEF, [w:] LYUM, s. 54; Đ. Matić, Pulskifilmski festival, [w:] LYUM, s. 323; R. Vukčević, Praxis, [w:] LYUM, s. 320 .

40 Niekiedy zresztą postaci nominalnie usytuowane poza (czy może raczej - we własnym mniemaniu - „ponad”) rzeczywistością popkultury, szczególnie liderzy polityczni, wkraczają do niej na skutek swoich cech i formułowanych przez siebie przekazów, dzięki podchwyceniu ich, dla celów pozapolitycznych (np. w zamiarze wykorzystania artystycznego), przez koryfeuszy kultury popularnej. Odpowiednim dla realiów jugosłowiańskich przykładem może być tu - jak wskazał D. Kršić - sam J. Broz Tito i np. wykorzystanie fragmentu z jednej z jego mów (wygłoszonej w latach 60. w Splicie i dotyczącej idei jugosłowiańskiego braterstwa i jedności oraz wierności wyborom politycznym poczynionym w 1948 roku związanym z przeciwstawienie się J. Stalinowi) w singlu pt. Panorama/Decree zespołu Laibach - zob. M. Marković, D. Kršić, B. Lenarčić, Titovi govori, [w:] LYUM, s. 396. 
Rzeczą zasługującą na podkreślenie jest, charakterystyczne dla Leksikonu - publikacji przybliżającej składowe mitologii jugosłowiańskiej popkultury - traktowanie co najmniej z pewną dozą powagi (mimo na ogół anegdotycznego, humorystycznego tonu) postaci ściśle związanych z kulturą popularną, a więc profesjonalnie ją tworzących, przy jednoczesnym opowiedzeniu się autorów publikacji za zupełnie odmienną metodą prezentowania odbiorcom sylwetek postaci, które do imaginarium popkultury weszły w sposób zgoła odmienny, jak to już podkreślono - z zasady nie mając wcale takiego zamiaru. Powyższe dotyczy zwłaszcza polityków. Warto zatrzymać się w tym miejscu na moment przy hasłach poświęconych: J. Brozowi Ticie, A. Rankoviciowi, M. Špiljakowi i M. Planinc.

Marszałek i prezydent Jugosławii (tę drugą funkcję zajmował J. Broz Tito najpierw kadencyjnie, zaś od zmian konstytucyjnych z 1974 roku dożywotnio), choć tak bardzo naznaczał jugosłowiańską rzeczywistość swoją osobą, legendą oraz rządami ${ }^{41}$, iż nie bez powodu mówi się o nim jako postaci mitycznej ${ }^{42}$, a także jako niemalże „zamienniku” dla pojęcia Jugosławia ${ }^{43}$, w poświęconym mu w Leksikonie haśle Dejana Novačicia przedstawiony zostaje w sposób iście komiczny. Autor z przymrużeniem oka przekonuje bowiem czytelników, że urodzony w Kumrovcu bohater napisanego przezeń hasła to ktoś przypominający jakimś cudem ożywioną postać z kina akcji. Towarzysz Tito prezentowany przez D. Novačicia, niczym bohater wartkiej filmowej fabuły (jej gotowy scenariusz podawać mogłyby biograficzne opracowania Vladimira Dedijera ${ }^{44}$ ), po dziecięcych wyczynach (przyjście na świat, zabicie świni w celu nakarmienia rodzeństwa, połamanie wykorzystywanego jako sanie koryta), udaje się do miasta Sisak uczyć się rzemiosła, a następnie na front wschodni, gdzie przytrafia mu się

${ }^{41}$ Zob. K. Kozub, Politycy z pierwszych stron gazet, Warszawa 1976, s. 371-376. Najnowsza wydana w Polsce biografia J. Broza Tity: P. Simić, Tito. Zagadka stulecia, Wrocław 2011. Interesujące przedstawienie propagandowego postrzegania jugosłowiańskiego prezydenta i marszałka w państwach komunistycznych związanych z ZSRR jako zdrajcy „bloku wschodniego”: B. Zieliński, Tito jako antybohater komunistycznego świata, [w:] Komunistyczni bohaterowie, t. 2, s. 175-193.

42 Por. L. Radenković, op. cit., s. 125-138. Zob. też: T. Rawski, Josip Broz Tito - charyzmatyczny przywódca? Analiza mitu wodza na przykładzie filmu „Sutjeska”, [w:] K. Taczyńska, S. Sochacki, M. Zečević (red.), op. cit., s. 279-292; M. Rekść, Jugonostalgia i titonostalgia..., s. 233-256.

43 Zob. M. Bogusławska, Tito od kuchni. Popularne (re)konstrukcje obrazu komunistycznej Jugosławii, [w:] Popkomunizm. Doświadczenie..., s. 251-270. W tekście tym autorka formułuje kwestię: „Mówimy Tito, myślimy - Jugosławia” (s. 270).

44 V. Dedijer, Josip Broz Tito - prilozi za biografiju, Beograd 1953 (także wydanie w jęz. esperanto: Josip Broz Tito - biografiaj notoj el vivo de Prezidento de Jugoslavio, Ljubljana 1954); idem, Novi prilozi za biografiju Josipa Broza Tita, t. 1-2, Zagreb-Rijeka 1980-1981. 
odniesienie rany - jakoby $\mathrm{z}$ rąk Czerkiesów, pochwycenie $\mathrm{w}$ rosyjską niewolę oraz ślub z nastoletnią Pelagią (Belousovą) ${ }^{45}$. Dalej widzimy Titę jako: pracownika Kominternu, sekretarza generalnego Komunistycznej Partii Jugosławii, więźnia, powstańca-rewolucjonistę, twórcę Antyfaszystowskiej Rady Narodowego Wyzwolenia Jugosławii, oswobodziciela ojczyzny, buntującego się przeciw Stalinowi przywódcę, kompana Winstona Churchilla w piciu whiskey, męża Jovanki, miłośnika muzyki i polowania na niedźwiedzie, założyciela Ruchu Państw Niezaangażowanych ${ }^{46}$, posiadacza białego munduru, rękawiczek i Rolexa. Na tym nie koniec - Tito to wszakże również miłośnik młodzieży (zwłaszcza przedstawicielek jej piękniejszej połowy), wina (chętnie popijanego z Richardem Burtonem) oraz cygar (naturalnie osobiście skombinowanych z Kuby).

Kulminacją prześmiewczego niby-biogramu Tity są jednak stwierdzenia autora dotyczące odejścia marszałka z tego świata:

Tito umarł w Lublanie i po krótkim postoju w Zagrzebiu pochowany został w Belgradzie. Ponieważ był dyktatorem, nikomu nie było żal, że umarł. Na jego pogrzeb też nikt nie przybył. A już na pewno nikt z zagranicy (świata). To w TV było zmontowane, a naoczni świadkowie kłamiąa ${ }^{47}$.

Aleksandar Ranković, zajmujący w Jugosławii pozycję „człowieka nr 2” do momentu odsunięcia go w 1966 roku przez J. Broza Titę i Komitet Centralny jugosłowiańskiej kompartii od wpływu na życie polityczne państwa ${ }^{48}$, na kartach Leksikonu, znalazł się jedynie dzięki krótkiemu hasłu napisanemu przez Vatroslava Sekulicia ${ }^{49}$. Warto podkreślić tutaj, iż ten autor, obok m.in.

45 Dostępny w Internecie biogram pierwszej żony J. Broza Tity - Rosjanki Pelagii Denisownej Biełousowej (1904-1968): http://sr.wikipedia.org/wiki//Пелагија_Белоусова [dostęp: 5.08.2013].

46 Zob. Nesvrstani, [w:] LYUM, s. 270 (tableau przedstawicieli 25 państw-uczestników belgradzkiej konferencji odbywającej się w dniach 1-6.09.1961). O Ruchu Państw Niezaangażowanych i scalających go ideach jako fenomenie posiadającym swoje postjugosłowiańskie „życie po życiu”: M. Bogusławska, Egzotyczni przyjaciele Josipa Broza Tity. O recepcji udziału SFRJ w Ruchu Państw Niezaangażowanych w perspektywie postjugosłowiańskiej, [w:] M. Bogusławska, Z. Grębecka, E. Wróblewska-Trochimiuk (red.), op. cit., s. 139-166.

47 D. Novačić, op. cit., s. 396. W oryginale: „Tito je umro u Ljubljani i, nakon kraćeg zadržavanja u Zagrebu, sahranjen je u Beogradu. Pošto je bio diktator, nikome nije bilo žao što je umro. Ni na sahranu mu niko nije došao. Pogotovo ne iz sveta. Ono na TV-u je montirano, a očevići lažu”.

48 Zob. W. Szczepański, Likwidacja polityczna Aleksandra Rankovicia i jej wpływ na przeobrażenia komunizmu jugosłowiańskiego, [w:] M. Bogusławska, Z. Grębecka (red.), Komunistyczni bohaterowie..., s. 195-209.

49 Zob. przyp. 29. 
wspomnianego wyżej D. Novačicia, jest jednym z tych współtwórców pomnika „hitów i mitów” jugosłowiańskiej popkultury, którzy w istotnej mierze wpłynęli na jego oryginalność w ten sposób, iż, decydując się zamieścić w Leksikonie hasła poświęcane osobistościom historycznym, opracowali je, dając w sposób wybitny dojść do głosu idiosynkrazji ${ }^{50}$. O, swego czasu „wszechmocnym”, szefie jugosłowiańskiej bezpieki, jakim był A. Ranković, znany również jako towarzysz Leka, napisał:

Nie mam pojęcia, kim on był [...], ale niektórym wygląda on na bardzo ważnego. [...] Gdyby był - byłoby im lepiej. Nie doszłoby do wszystkiego tego. Czego? Wszystkiego. Jego pogrzeb [...] był w swoim czasie najpotężniejszym koncertem w Bg. (Belgradzie). [...] Często go wspominają w filmach - między wierszami ${ }^{51}$.

Anonimowy autor hasła dotyczącego chorwackiego działacza politycznego Miki Špiljaka również dostarcza odbiorcy sugestywnej, osobistej, nasączonej ironią notki na temat jednego $\mathrm{z}$ wielu, niczym szczególnym się w sumie niewyróżniających polityków, których szczyt kariery przypadł w dobie posttitowskiej już Jugosławii (w przypadku M. Špiljaka było nim stanięcie na czele kolegialnej prezydentury SFRJ w 1983 roku). Opisujący tego polityka nieznany $\mathrm{z}$ imienia i nazwiska współautor Leksikonu wspomina go jako jednego z wielu aparatczyków i biurokratów, który przeszedł jednak do historii jako charakterystyczny, siwy, noszący niemodne okulary rozmówca Ronalda Reagana, który po powrocie ze Stanów Zjednoczonych do Jugosławii zyskał w niej przezwisko „Majk Spajk”. Obraz „niewstydzącego się niczego” M. Špiljaka u boku amerykańskiego gospodarza Białego Domu oraz treść oficjalnej relacji poświęconej wizycie jugosłowiańskiego polityka w Waszyngtonie były dla autora jego leksykonowego biogramiku niczym „fantastyka naukowa" ${ }^{2}$.

Sylwetkę byłej premier SFRJ Milki Planinc, o której Marcus Tanner napisał, że była postacią o wiele mniej popularną od innej Chorwatki zaangażowanej wcześniej w jugosłowiańską politykę - Savki Dabčević-Kučar (dysydentki,

50 A. Radak, Od Adrije..., s. 13. Autor hasła dotyczącego A. Rankovicia opublikował również w kilka lat po ukazaniu się Leksikonu tekst poświęcony jugosłowiańskiemu (pochodzącemu z Serbii) popularnemu aktorowi Igorowi Galo, podkreślając, że nota o nim zasługuje na znalezienie się w tym wyjątkowym dziele: V. Sekulić, Novi prilozi za Leksikon YU mitologije, „Novosti” 2009, nr 519 (26.11.), http://www.novosti.com/2009/11/ novi-prilozi-za-leksikon-yu-mitologije/ [dostęp: 5.08.2013].

51 W oryginale: „Ne mam pojma koji im je taj [...] ali nekima je izgleda jako važan. [...]. Da je njega bilo bi im bolje. Ne bi došlo do svega ovoga. Kojega? Svega. Njegov sprovod je [...] bio najjači koncert tih godina u Bg. [...]. Puno ga spominju u filmovima, između redova" - V. Sekulić, Ranković..., s. 333

52 Đ. Matić, Špiljak..., s. 338. 
liderki tzw. chorwackiej wiosny $)^{53}$, scharakteryzowała w Leksikonie Sandra Antolić. I jej bliskie okazało się idiosynkratyczne spojrzenie na opisywaną osobę, należącą przez część lat 80. XX wieku do grona najważniejszych jugosłowiańskich polityków. Notka o M. Planinc, poza wskazaniem piastowanej przez nią funkcji premiera, nie przynosi żadnych istotnych danych. Pada w niej jednak informacja o tym, iż swego czasu w Jugosławii mawiało się o chorwackiej pani premier, iż zaczesuje ona w charakterystyczny sposób włosy pod górę, aby myślano, że przyjeżdża na miejsce pełnienia służby państwowej rowerem, gdy tymczasem codziennie rano przylatywała do Belgradu specjalnym samolotem rządowym ${ }^{54}$.

Interesującą kwestią może się z pewnością wydać, iż jednej z ostatnich ważnych postaci politycznych dziejów SFRJ, zapamiętanej z niej nawet przez laików bodaj najlepiej obok osoby J. Broza Tity, czyli Slobodanowi Miloševiciowi (1941-2006) w Leksikonie nie poświęcono odrębnego hasła, mimo że wspominany jest on w tej publikacji kilkakrotnie ${ }^{55}$. Tym większym zaskoczeniem może być więc odnalezienie napisanej przez Đorđe Maticia notki rozpoczętej imieniem i nazwiskiem Slobodan Milošević wewnątrz dwuczęściowego hasła pt. Some boys (współautorem całego hasła jest Branko Rosić) ${ }^{56}$. O co chodzi? Otóż wspomniane imię i nazwisko, niezwykle popularne w Serbii, należały do głównego bohatera kultowego filmu pt. Chłopak, który obiecuje (serb. Dečko koji obećava), wyreżyserowanego w 1981 roku przez Mišę Radivojevicia. Filmowy Slobodan, grany przez Aleksandara Berčeka, jest ustatkowanym studentem i troskliwym partnerem swojej dziewczyny, aż do czasu wdania się w romans ze starszą od siebie, wyzwoloną Szwajcarką. Po nim zachodzi w bohaterze zasadnicza zmiana - młody S. Milošević staje się bowiem rockowym buntowni-

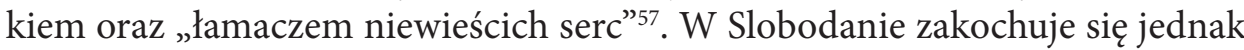
rocker Pit - homoseksualista, wyśpiewujący w pewnym momencie pod adresem obiektu swoich westchnień: „ja nie chcę najlepszej dziewczyny..., gdyż ty jesteś mój - i ja jestem twój, chcę wrócić do ciebie”. W końcu Pit zabija się z powodu S. Miloševicia. Słowami Some boys indeed! Đ. Matić kończy swoje, dedykowane Slobodanowi Miloševicowi, (pod)hasło, stanowiące element większej całości dotyczącej motywów homoseksualnych w muzyce rozrywkowej oraz

53 M. Tanner, Chorwaci, [w:] Chorwacja, E. Kosiba (red.), Warszawa 2007, s. 55.

54 S. Antolić, Planinc..., s. 310.

55 LYUM, s. 13, 38, 102, 207, 220, 256, 336, 388.

56 B. Rosić, Đ. Matić, Some boys, [w:] LYUM, s. 363-364. Treść hasła uzupełnia zdjęcie, pochodzące $\mathrm{z}$ lat 50. ubiegłego wieku, wymownie korespondujące $\mathrm{z}$ tekstem (s. 364). Przedstawieni są na nim dwaj wioślarze klubu Mladost z Zagrzebia, przebywający na splickim wzgórzu Marijan.

${ }^{57}$ http://www.filmweb.pl/film/Decko+koji+obecava-1981-222253 [dostęp: 6.08.2013]. 
filmie z czasów SFR ${ }^{58}$. Zapewne inny, osadzony w areszcie w Scheveningen, S. Milošević, mający wówczas na głowie zupełnie inne problemy, nie zaczytywał się w Leksikonie YU mitologije. Film M. Radivojevicia mógł on jednak kiedyś mieć okazję obejrzeć...

W ślad za dotychczasowymi recenzentami i interpretatorami Leksikonu, takimi jak chociażby autorka jednego z ciekawszych tekstów na jego temat, Iva Pauker $\mathrm{z}$ australijskiego Melbourne ${ }^{59}$, można by rozwijać wywody na temat jego struktury oraz poszczególnych haseł, koncentrując się ewentualnie na jakiejś ich grupie (wspomniana badaczka bliżej odnosi się np. do not poświęconych jugosłowiańskiej muzyce rozrywkowej ${ }^{60}$ ). Wystarczy jednak zaznaczyć raz jeszcze to, co sygnalizowano już wcześniej, a mianowicie - niesamowitą różnorodność postaci, przedmiotów, wydarzeń i różnych zagadnień, ujętych w publikacji poświęconej mitom jugosłowiańskiej kultury popularnej. Obok wspominanych już - nieco na przekór - polityków, których popkultura, nawet wbrew ich woli, zdolna jest przepoczwarzać ze zdystansowanych do niej „poważnych osobistości” w komponenty swej własnej, wielkiej i charakteryzującej się wieloaspektowością struktury, obok gwiazd i gwiazdek sceny muzycznej czy filmu, tudzież sportowców, wertujący karty Leksikonu natrafią na całą galaktykę pojęć odnoszących się do przeróżnych sfer egzystencji Jugosłowian i Jugosłowianek w ich wspólnym, komunistycznym państwie. Nie sposób oprzeć się pokusie wymienienia takich, jak np.: pięcioramienna czerwona gwiazda, wszechobecne w przestrzeni publicznej portrety Tity, mające być znakiem niezachwianej wiary społeczeństwa w swego przywódcę i w jugosłowiańską jedność, KPJ (Komunistyczna Partia Jugosławii), pasta do zębów Kalodent, komiksy, filmy partyzanckie, szkolne przedmioty nauczania typu „Kryzys kapitalizmu a socjalizm - procesy globalne” (serb. kriza kapitalizma $i$ socijalizam kao svetski proces $)^{61}$, rakija, burek, macedońskie gravče na tavče, wojskowe szkolenie taktyczne, „zdrowe siły” (serb. zdrave snage - partyjne, państwowe, wszelakie!), subkultura punkowa, szkolne piórniki, kawiarniane rytmy, wakacyjne/urlopowe pobyty na wyspie Mljet (mljetovanje), banknot Stoja (100 YUD), charakterystyczny dla języka macedońskiego przyrostek „ta” (maced. cyrylica - тa), czarnogórskie Nikšićko pivo, przewoźnik lotniczy JAT, nocne życie Zagrzebia, knajpa Šansa w belgradzkim parku Tašmajdan (nazywana „Ostatnią szansą" - serb. Poslednja šansa, ze względu na to, że zamykano ją dopiero o 5.00 nad ranem), żel do włosów Valera, jugosłowiański

58 Đ. Matić, Some..., s. 364. Treść cytatu w oryginale: „ja neću najbolju devojku... jer ti si moj - i ja sam tvoj, želim da se vratim tebi”.

59 I. Pauker, op. cit., s. 72-81.

60 Ibidem, s. 75-77.

${ }_{61}$ M. Borić, Kriza, [w:] LYUM, s. 203. 
(chorwacki) brand-produkt Vegeta, imiona nadawane niekiedy w SFRJ przez słowiańskich i albańskich rodziców dzieciom, wskazujące na fatalne zauroczenie komunizmem lub rusofilstwo (Traktorka, Lenjin, Staljin, Volga, Kaqusha, a nawet Lems - akronim utworzony od Lenin, Engels, Marks i Stalin ${ }^{62}$, Dynastia w telewizji, miejscowość Kovin (znana z tzw. psychiatryka i dzięki temu funkcjonująca w powiedzeniach mieszkańców Serbii, a zwłaszcza Banatu, tak jak w polszczyźnie Tworki)... Dość!

Czy ta gmatwanina pojęć - znaków firmowych państwowości jugosłowiańskiej oraz jugosłowiańskiej popkultury, jej ikon, ale i błahostek, tworzy pospołu jakiś jeden, spójny jugosłowiański mit czy może lepiej mit jugosłowiańskości, który ex post uznać można by za konstytuujący w istotnym stopniu coś takiego jak tożsamość jugosłowiańska? Za pomysłodawcami Leksikonu odpowiedzieć można, że raczej nie.

Opinię tę zdaje się podzielać także Milena Dragičević-Šešić - profesor kulturoznawstwa $\mathrm{z}$ Belgradu ${ }^{63}$. W rozmowie ze znanym belgradzkim dziennikarzem Omarem Karabegiem, w której uczestniczył również politolog z Zagrzebia Ivo Žanić, stwierdziła ona bowiem, że choć Jugosławia w pamięci zbiorowej w pewnym sensie stała się już mitem (rzeczywistością mityczną), to mit (o) Jugosławii, przekaz formułowany na jej temat, nie jest bynajmniej żadną spójną całością narracyjną. Sam Leksikon YU mitologije dla przywołanej badaczki najlepiej odsłania fakt nieistnienia jakiegoś centralnego mitu jugosłowiańskiego, mitu z prawdziwego zdarzenia, mającego solidne fundamenty. Nie ma więc - jak przekonuje M. Dragičević-Šešić - jednego mitu; są za to drobiażdżki w postaci różnych już to cukierków, już to aut (znów „kłania się” fića!), te jednak, choć dla wielu stanowiły istotne symbole odnoszące się do ich życia w Jugosławii, na pamiętaniu których aktualnie usiłuje się budować opowieść o tym państwie, to zbyt mało, by powstał i przetrwał prawdziwy mit jugosłowiański ${ }^{64}$.

Wydaje się, że choć ów mit jugosłowiański, taki, jakim chciałaby go widzieć M. Dragičević-Šešić, istotnie nie powstał. Zauważyć należałoby jednak, że niezależnie od powyższego w komunistycznej Jugosławii dość licznie pojawiały się różne mityzowane idee. Nadto w SFRJ dochodziło do mityzacji i nowego definiowania

${ }^{62}$ Wymienione przykłady za: Đ. Matić, Jashari, Kaqusha, [w:] LYUM, s. 169. Wspomniane imię Lems nosi m.in. znany chorwacki lekarz z Puli Lems Jerin. Zob. http://hr.linkedin. com/pub/lems-jerin/5/521/905 [dostęp: 6.08.2013]. Imię Kaqusha nosi bohaterka wyżej cytowanej notki autorstwa Đ. Maticia - albańska polityk, premier autonomicznego, jugosłowiańskiego Kosowa w latach 1987-1989. Zob. http://en.wikipedia.org/wiki/ Kaqusha_Jashari [dostęp: 6.08.2013].

63 Sylwetka M. Dragičević-Šešić: http://www.culturecongress.eu/people/sesic_milena [dostęp: 7.08.2013].

${ }^{64}$ M. Dragičević-Šešić, [w:] Ko je dobro, a ko loše prošao..., s. 6. 
idei rodem z Jugosławii przedtitowskiej, na czele z samym polityczno-kulturowym konceptem jugoslawizmu, jak również - niejako wbrew projektowi wykreowania jednej jugosłowiańskiej świadomości narodowej - do reinterpretacji mitów organizujących tożsamości poszczególnych narodów jugosłowiańskich. Niewątpliwie jednak w warunkach federacji, której podmioty zintegrowane zostały wokół osoby Tity i jugokomunizmu, wytworzony został wieloskładnikowy system symboli, pojęć i znaczeń, budujący jugosłowiańską mitologię, a nawet szerzej - specyficzną jugosłowiańską przestrzeń znaków, wspólną przestrzeń kulturową, umożliwiającą komunikację społeczną w tym niehomogenicznym organizmie.

Odwoływanie się do tej przestrzeni, przypominanie o niej, jest czymś naturalnym. Jest efektem nostalgii, ale i czymś więcej. To także zajęcie autoterapeutyczne dla części „post-Jugosłowian”. To zanurzenie się tych, którzy odczuwają taką potrzebę w strumieniu własnej przeszłości, odkłamujące, a jednocześnie po części ją rehabilitujące czy wręcz uwznioślające, stwarzające okazję do powiedzenia sobie samemu, że tak się po prostu żyło, że nie było przecież tak źle i, ogólnie rzecz biorąc, to nie ma się czego wstydzić. Dodatkowo pojawia się aspekt powojennego przywracania pamięci o utraconej wspólnej przestrzeni (politycznej, kulturowej, egzystencjalnej, geograficznej) - tak niedawno podzielonej przez konflikty i ostateczny rozpad federacyjnego państwa, w następstwie czego niegdysiejsza, wspólnotowa, względna wielkość wyparta została przez obecną, jednostkową, bezwzględną skarlałość.

Niełatwe to zadanie - ocalać od zapomnienia to, co łączyło, co czyniło wspólnotowy byt radośniejszym. Spojrzeć z poczuciem humoru, zaprawionym domieszką ironii, na zasługującą (mimo wszystko) na przywrócenie do zbiorowej pamięci wspólną przeszłość, tak ostro negowaną w czasie, w którym świadomość społeczną w nowo powstałych państwach postjugosłowiańskich hodowano na glebie nacjonalizmów ${ }^{65}$. Podczas gdy jedni tak zaprogramowanym działaniom przyklaskują, drudzy odnoszą się do nich ze sceptycyzmem, a czasem i z jednoznaczną krytyką. Są i tacy, którzy dają wyraz postawie ambiwalentnej. Największe kontrowersje rzecz wzbudza wśród Serbów i Chorwatów.

Wśród tych pierwszych - jak zauważyła choćby M. Dragičević-Šešić - wchodzą ze sobą w spór wyraziciele dwóch poglądów na temat jugosłowiańskiej przeszłości. Dla jednej opcji, SFRJ jawi się jako więzienie, w którym nie dane było Serbom być wielkimi, wolnymi, swobodnie rozwijającymi potencjał polityczny, ekonomiczny i kulturowy własnej wspólnoty narodowej, a więc jako frontalna porażka serbskości. Dla drugiej - której reprezentantami z pewnością byli serbscy współtwórcy Leksikonu, jak też ci spośród Serbów, którzy z entuzjazmem przyjęli pojawienie się tej publikacji, wspólna państwowość

${ }_{65}$ Zob. M. Rekść, Jugonostalgia i titonostalgia..., s. 241. 
jugosłowiańska była upostaciowieniem idei jedności bliskich sobie nacji, zintegrowanych wokół serbskiego Piemontu, zdolnych do wspólnotowego budowania podmiotowej pozycji w międzynarodowych stosunkach politycznych i gospodarczych, a także do osiągania coraz wyższego poziomu kulturowego ${ }^{66}$.

Omówiony dualizm postaw spotyka się również wśród Chorwatów. Wielu z nich Leksikon współtworzyło. Chętnie doń w Chorwacji sięgano. Z inspiracji dostarczanych przez zawarte w nim treści zrodziły się dość niekonwencjonalne projekty kulturalne - ekspozycja muzealna, a nawet, zyskujące spory oddźwięk, przedstawienie teatralne, współtworzone w Puli przez partnerów z pięciu pozostałych republik byłej Jugosławii oraz z Kosowa. Komentatorzy, ceniący sobie powstałe w belgradzko-zagrzebskiej kooperatywie dzieło - książkowy pomnik jugosłowiańskiej popkultury, dostrzegali, że zaangażowani w jego wykreowanie Serbowie to zwolennicy antyhegemonistycznej narracji o czasach jugosłowiańskich, a nie jacyś zawzięci nacjonaliści ${ }^{67}$. Często jednak tego rodzaju opiniom towarzyszyły „glosy”, wypowiadane przez te same, a więc zachowujące się z pewną ambiwalencją, osoby. Ich wypowiedzi dostarczały analiz zagrożeń wynikających z roztkliwiania się nad wspólnotową przeszłością, z opisywania jej na sposób idiosynkratyczny, z naiwnego i dezorientującego, a w ostateczności wręcz manipulacyjnego eksponowania toposów codzienności, jako rzekomo wystarczająco dobrze ukazujących realia życia „pod komunizmem”, bez jednoczesnego przywoływania szerszego kontekstu i pozostawiania miejsca na inne interpretacje (Rade Dragojević) ${ }^{68}$. W poświęconej leksykonowi jugosłowiańskiej mitologii chorwacko-serbskiej dyskusji w audycji Kontrapunkt Radia Wolna Europa (chor. Radijo Slobodna Evropa), której zapis znalazł się na łamach czasopisma ,Zarez” (nr z 17.06.2004), chorwacki krytyk literacki Branimir Donat zarzucał twórcom Leksikonu odmalowywanie przeszłości w sposób subiektywny, sentymentalny i selektywny, pokazywanie jej przypudrowanej, atrakcyjnej, bez podejmowania prób demistyfikacji jugonostalgii. Serbski historyk Radoš Ljušić przyszedł mu w sukurs określeniem postawy jugonostalgicznej mianem utopijnej, a żalu za byłą Jugosławią jako nieuzasadnionego ${ }^{69}$.

${ }^{66}$ M. Dragičević-Šešić, [w:] Ko je dobro, a ko loše prošao..., s. 6.

67 R. Dragojević, op. cit., s. 1-2.

${ }^{68}$ Ibidem (przywoływany tekst, pochodzący z początku stycznia 2013 roku, zawiera odniesienia do Leksikonu, w swej zasadniczej części poświęcony jest jednak wystawie muzealnej pt. „Refleksije vremena 1945-1955, Zagrzeb, Klovićevi dvori”, ekspozycji trwającej do 10.03.2013).

${ }^{69}$ S. Kostić, op. cit., s. 12. Obok wymienionych w radiowej dyskusji o Leksikonie uczestniczyli również Đ. Matić i V. Arsenijević. O różnicach w postrzeganiu jugonostalgii wśród Serbów i Chorwatów (a także Słoweńców) pisała ostatnio, wychodząc od obserwacji Karla-Markusa Gaussa (por. idem, Europejski alfabet, Warszawa 2008), Lilla 
Jednoznacznie negatywnie o promowaniu jugonostalgicznego spojrzenia na niedawną przeszłość przez autorów i chwalców Leksikonu oraz przez twórców innych projektów, inspirowanych treścią tegoż, wypowiedziała się za to w Chorwacji prawicowa publicystka Petra Jurčević, znana z publikacji na portalu hrsvijet.net, z których część powielana bywa m.in. na stronie internetowej www.braniteljski-portal.hr ${ }^{70}$. Autorka ta, która formułuje swoje opinie w sposób jednoznacznie uwidaczniający związek między konstruowanymi strukturami pojęciowymi a przyjmowaną orientacją polityczno-ideologiczną $^{71}$, zbulwersowana była faktem wykorzystywania Leksikonu w, jej zdaniem propagandowym - służącym dobrze racjom serbskim, źle zaś chorwackim krzewieniu sentymentów względem SFRJ, w której Chorwatom żyło się źle, i której krwawy rozpad był niczym innym jak rozprawą z Chorwatami i Chorwatkami - masakrowanymi, prześladowanymi i gwałconymi przez Serbów ${ }^{72}$. P. Jurčević jednoznacznie potępiała wystawienie z wielką pompą w Istryjskim Teatrze Narodowym (chor. Istarsko narodno kazalište) w Puli w dniu 2.12.2011 roku spektaklu zatytułowanego Leksikon YU mitologije w reżyserii Olivera Frljicia, tworzonego w koprodukcji z takimi podmiotami, jak: NETA (chor. Nova europska teatarska akcija), Festival Ex Ponto z Lublany, Czarnogórski Teatr Narodowy z Podgoricy, Mały Teatr Dramatyczny z Bitoli, Stowarzyszenie Kultura nova z Nowego Sadu oraz Teatr Narodowy z Prisztiny ${ }^{73}$. Autorka

Moroz-Grzelak - „[...] to samo zjawisko w Chorwacji zyskało zupełnie odmienne znaczenie. [...] osobę zdemaskowaną jako "jugonostalgika« uznaje się za pasożyta na ciele narodu chorwackiego, tęskniącego za hańbą, jaką znosić musieli Chorwaci w Jugosławii. Określenie to z łatwością przypisuje się [...] każdemu, kto odważy się krytykować chorwacki nacjonalizm" (L. Moroz-Grzelak, Granice i pamięć jako kategorie południowosłowiańskiej rzeczywistości - kompensacyjne mitotwórstwo, rewizja historii, jugonostalgia, [w:] Międzycywilizacyjny dialog w świecie słowiańskim w XX i XXI wieku, I. Stawowy--Kawka (red.), Kraków 2012, s. 26).

70 Ustalenie powyższego za pomocą wyszukiwarki google.com.pl: https://www.google.pl/ search?q=Petra+Jur\%C4\%8Devi\%C4\%87\&ie=utf-8\&oe=utf-8\&rls=org.mozilla:pl:official\&client=firefox-a\&gws_rd=Cr [dostęp: 8.08.2013].

${ }^{71}$ Związek tego rodzaju opisywany jest w literaturze przedmiotu szczegółowo przez Thomasa Eckesa, a w literaturze powstałej na gruncie polskim spożytkowany przez Janusza Reykowskiego i Danko Šipkę. Zob. T. Eckes, Politische Orientierung und die semantische Struktur politischer Begriffe, ,Zeitschrift für Sozialpsychologie” 1986, vol. 4, s. 255-269; J. Reykowski, Poziom politycznego myślenia a rozwiązywanie społecznych zadań koordynacyjnych, „Czasopismo Psychologiczne” 1996, nr 1, t. 2, s. 7-30; D. Šipka, Demokracja a interes narodowy $w$ ujmowaniu sytuacji politycznej: przykład wojny $w$ dawnej Jugosławii, Poznań 2002, s. 85.

72 P. Jurčević, op. cit., s. 1-2.

73 Ibidem. Na temat samego O. Frljicia, chorwackiego reżysera teatralnego pochodzącego z miasta Travnik w BiH, i jego kontrowersyjnych spektakli wystawianych w różnych 
z niesmakiem skwitowała również zachwalanie spektaklu przez zwolenników wydania Trybunałowi ds. zbrodni w byłej Jugosławii gen. Ante Gotoviny oraz przeciwników zorganizowania swego czasu w Puli koncertu chorwackiego nacjonalistycznego piosenkarza Marko Perkovicia Thompsona ${ }^{74}$. Tekst Chorwatki, kwestionującej sens interesowania się przez jej rodaków inicjatywami takimi, jak wydanie Leksikonu czy też innymi przedsięwzięciami artystycznymi, wyrosłymi na gruncie - zdaniem P. Jurčević - niepotrzebnej i szkodliwej popularności tego dzieła, ilustruje fotografia przedstawiająca prezydenta Serbii Borisa Tadicia, wręczającego księgę upamiętniającą dziedzictwo jugosłowiańskiej popkultury prezydentowi Chorwacji Ivo Josipoviciovi. Warto dodać, że pod fotografią widniał podpis: „z okazji 20. rocznicy kapitulacji Vukovaru”75. Jakże odległe to w swoim wydźwięku od głosów innych komentatorów (głównie serbskich, choć cytowanych, a niekiedy i wspieranych także przez Chorwatów), dopatrujących się w geście B. Tadicia czegoś pozytywnego ${ }^{76}$.

Prowokując, z perspektywy w sumie tużpowojennej, pytania o niedawną wspólną przeszłość społeczności postjugosłowiańskich i o paradygmaty jugosłowiańskiej kultury, postulując wskrzeszenie dyskursu o wspólnej przestrzeni kulturowej oraz o funkcjonujących w niej mitach, Leksikon stwarza okazję do rozrachunków z nieodległą, pełną kontrowersji i emocji, przeszłością ${ }^{77}$. Jako dzieło stanowiące próbę odszukania (rekonstrukcji?) tożsamości jugosłowiańskiej/ich doby komunistycznej poprzez opisanie fenomenów ówczesnej jugosłowiańskiej kultury Leksikon - jak konstatują dziennikarze prowadzący wspominaną wyżej, przeprowadzoną w połowie 2004 roku, serbsko-chorwacką radiową dyskusję nad tym dziełem - nie może pozostawić obojętnym ${ }^{78}$. Zwłaszcza że, analizując głębiej zawarte w nim pojęcia, nie sposób uniknąć przeświadczenia, że jeszcze przez długie lata, przeżywszy agonię państwa jugosłowiańskiego, będą one żywe (fenomen ,życia po życiu”) i nieodzowne dla komunikowania się grup i jednostek z obszaru ex-Jugosławii ${ }^{79}$, dla prowadzonego

częściach Europy pisano w ostatnim czasie sporo także w Polsce (w związku z przygotowaniami do wystawienia w Starym Teatrze w Krakowie Nie-Boskiej komedii Zygmunta Krasińskiego). Zob. W. Stanisławski (współpraca A. Konikiewicz), Oskarżyciel objazdowy, „Rzeczpospolita” (dodatek „Plus Minus”) 2013, 7-8.12., s. P16-P17; G. Andrijanić, Bałkański skandalista w Krakowie, „w Sieci” 2013, 9-15.12., s. 66-67.

74 P. Jurčević, op. cit., s. 1-2.

75 Ibidem.

76 M. Dragičević-Šešić, [w:] Ko je dobro, a ko loše prošao..., s. 4.

77 S. Kostić, op. cit., s. 12.

78 Ibidem.

79 Ibidem. 
$\mathrm{w}$ tej przestrzeni dyskursu ${ }^{80}$. Dążenie do wymazania z pamięci zbiorowej doświadczeń i swoistości jugosłowiańskiej przeszłości dyskurs ów mogłoby jedynie zubożyć, a zwolenników ucieczki z postjugosłowiańskiej przestrzeni kulturowej skazać na izolacjonizm. Dostrzegł to m.in. słoweński pisarz i poeta Aleš Debeljak. Zauważają zaś ową kwestię ostatnio (także na gruncie polskim), za wspomnianym twórcą ze Słowenii i za innymi autorami, analitycy paradoksów, w które obfitują aktualne spory o pamięć i ocenę wspólnotowej przeszłości społeczności jugosłowiańskich ${ }^{81}$.

Inną kwestią jest jednak to, jak w realiach postjugosłowiańskich żyją, po swoim wcześniejszym, jugosłowiańskim życiu, fenomeny wspólnotowej przeszłości, i jak funkcjonuje pamięć o nich. Coraz mniej jest np. w przestrzeni postjugosłowiańskiej świadomości więzi historycznych narodów byłej SFRJ (także tych starszych, wielowiekowych), coraz mniejsza zdaje się być znajomość geografii obszaru (wydaje się, iż więcej młodych Chorwatów, Bośniaków, Serbów czy Albańczyków z Kosowa zlokalizuje w miarę szybko na mapie Europy bawarskie Garmisch-Partenkirchen lub grecką Leptokarię niż słoweński Bled czy macedoński Stari Dojran). Postjugosłowiańską pamięć kształtują przede wszystkim toposy życia codziennego i zjawiska popkultury.

Opisujący je Leksikon dostarcza jednak mimo to inspiracji nie tylko dla snucia przez jugonostalgików wspomnień o grach, zabawach, piosenkach i smakołykach z czasów SFRJ, ale także do dyskusji zwolenników i nieprzejednanych wrogów byłej Jugosławii o polityce, historii, szeregu spraw społecznych ${ }^{82}$.

W dysputach takich zaś w centrum stawiane są częstokroć idee i mity, a ewentualne

80 Szersze rozważania w przedmiocie definiowania pojęcia „dyskurs”, m.in. w: Dyskurs jako struktura i proces, T.A. van Dijk (red.), Warszawa 2001; M. Kawka, P. Płaneta, Dyskursy o Macedonii, Kraków 2013, s. 13-22, 125-127.

81 Zob. np. L. Moroz-Grzelak, op. cit., s. 26-27 (autorka sięga m.in. do tekstu: A. Debeljak, Moje Bałkany: erozja pamięci i wypływajace z niej zagrożenia, „Krasnogruda” 2002/2003, nr 16, s. 9-18).

82 Jak pisze L. Moroz-Grzelak w korespondujących z niniejszymi uwagami passusach cytowanego już wyżej artykułu, które notabene mogłyby uzupełniać także wcześniejsze partie niniejszego tekstu skoncentrowane na kwestii jugonostalgii i pamięci postjugosłowiańskiej - „Wspólnota państwowa, która spajała przez lata zróżnicowane, ale etnicznie bliskie sobie narody, zyskała znaczenie kulturowe. Po latach zaowocowała zjawiskiem jugonostalgii, która nie jest li tylko satyrycznym bądź dramatycznym opisem rzeczywistości przedstawianej w literaturze jako tęsknota za federacyjną Jugosławią i jej wieloletnim prezydentem, który dbał o jedność jej struktur. Natomiast zdystansowanie wobec tej przeszłości nie oznaczało wcale wymazywania jej z pamięci. [...] Piętnowana przez jednych, a pielęgnowana przez innych pamięć o wspólnej przeszłości znajduje również swój społeczny wymiar” - L. Moroz-Grzelak, op. cit., s. 26-27. 
[...] obalenie mitu nie oznacza unicestwienia jego przestrzeni, ale transpozycję w nowy przekaz, zajmujący równorzędne miejsce w stosunku do poprzedniego. Wszelkie procesy mitoburstwa, nie obejmujące jednak mitycznych konarów, mogą więc jedynie oznaczać dalsze mitotwórstwo ${ }^{83}$.

Idee i mity trwają zatem, a przy tym transformują świadomość odwołujących się do nich ludzi. Chyba, że - jak pisał o nich Andrzej Sepkowski - mowa o ideach wyzutych $\mathrm{z}$, ,[...] mocnej podbudowy aksjonormatywnej, [które] miewają żywot jętek" 84 .

Rolę odgrywaną przez mity, w tym mity polityczne, we współtworzącym świadomość społeczną ,,zbiorze wyobrażeń, symboli, pojęć, opinii, poglądów i przesądów" trudno przecenić ${ }^{85}$. Ta ogólna uwaga powinna być odnoszona także do uwarunkowań realiów postjugosłowiańskich. Również o tamtejszych mitach powiedzieć można za Jerzym Zalewskim, że proponują one własną rzeczywistość, a ich sukces zależy od percepcji wiarygodności ${ }^{86}$, i że:

jeśli mają one sens dla ludzi, którzy chcą w nie uwierzyć, spełniają wówczas najważniejsze zadanie: dostarczają człowiekowi poczucia tożsamości i orientacji w zdefragmentowanym świecie. Mit rodzi się z rozbieżności między światem realnym a światem nowych aspiracji; odpowiada na pytanie o tożsamość, wspólnotę, podstawy i sens naszej egzystencji. Odpowiada również na zapotrzebowanie oczekiwań wspólnoty, jej nadziei, ideałów, posiadania poczucia tego, czym chciałaby być. Mit jest więc zarówno formą kontemplacji, jak i wezwaniem do działania ${ }^{87}$.

Czytelnik zagłębiający się w treść Leksikonu YU mitologije, realizuje intelektualną wędrówkę po zdefragmentowanym świecie byłej Jugosławii. Odczytuje zeń wykładnię starej, minionej już jugosłowiańskiej rzeczywistości, stanowiącą próbę odpowiedzenia na pytania o tożsamość, wspólnotę, podstawy, a nawet

${ }_{83}$ M. Rekść, Mity narodowe i ich rola w kreowaniu polityki na przykładzie państw byłej Jugosławii, Łódź 2013, s. 55.

84 A. Sepkowski, Ideologie w przestrzeni mitycznej, [w:] Mity historyczno-polityczne, wyobrażenia zbiorowe, polityka historyczna. Studia i materiały, t. 2, E. Ponczek, A. Sepkowski (red.), Toruń 2012, s. 16.

${ }^{85}$ J. Zdański, Współczesny mit polityczny - forma świadomości społecznej, [w:] ibidem, s. 36. Jerzy Zdański posługuje się definicją „,mitu politycznego” sformułowaną przez Tadeusza Biernata. Jest on „swego rodzaju formą świadomości społecznej, powstałą jako korelat określonych procesów poznawczych, informacyjnych, emocji, która wywołuje z góry dający się przewidzieć irracjonalny stosunek do rzeczywistości, modyfikujący tę rzeczywistość, tworzący jej wyobrażenie".

86 J. Zalewski, Tęsknota za mitem możliwościa wypetniania próżni politycznej, [w:] Mity historyczno-polityczne, wyobrażenia zbiorowe, polityka historyczna. Studia i materiały, t. 3, E. Ponczek, A. Sepkowski, M. Rekść (red.), Torun 2013, s. 36.

${ }^{87}$ Ibidem. 
i sens egzystencji, formułowaną przez autorów wywodzących się ze społeczności zakorzenionych w przeszłości, lecz spoglądających także w przyszłość, mierzących się z rozdźwiękiem między światem realnym i światem własnych, nowych aspiracji, nie tylko medytujących nad tym co było, ale i szukających - głównie w doświadczeniach z przeszłości - inspiracji do teraźniejszych i przyszłych działań.

Na drodze do sformułowania programów, z którymi będzie można wkraczać w błyskawicznie przeobrażające się ,teraz" i w niepewne jutro, drogowskazami mogą pozostawać pieczołowicie zlustrowane, atrakcyjnie ukazane na kartach Leksikonu i - chciałoby się rzec - obdarzone nowym życiem, znaki, symbole $\mathrm{i}$ inne treści kulturowe. Ocalone zostały one bowiem od zapomnienia $\mathrm{z}$ rezerwuaru niedawnej wspólnotowej przeszłości - wymiaru, którego nie udaje się unieważnić zwolennikom pogrzebania szerokiej, postjugosłowiańskiej przestrzeni społeczno-kulturowej, orędującym za budową nowych, nieliczących się z wcześniejszym wspólnotowym dziedzictwem, tożsamości, nawet za cenę izolacji i zawężenia horyzontów poznawczych obywateli poszczególnych państw powstałych z rozpadu byłej Jugosławii, tego dawnego ,absolutnego top-szpanu", dla nas Polaków (w Leksikonie utożsamionych notabene wyłącznie z zaglądającymi na obszar jugosłowiański handlarzami ${ }^{88}$ ) „bijącego na głowę Sopot, a nawet Bułgarię" 89 .

\section{Bibliografia}

Adrić I., The Lexicon of Yu-Mythology: 1989-2001, „Newsletter” 2001, no. 9, http://www.ceebp.org/Nwslet9June2001.htm [dostęp: 13.07.2013].

Adrić I., Arsenijević V., Matić Đ., Leksikon YU mitologije, Beograd 2005.

Andrijanić G., Bałkański skandalista w Krakowie, „w Sieci” 2013, 9-15.12.

Binda K., Zastawa 750 po Jugosławii, [w:] Popkomunizm. Doświadczenie komunizmu a kultura popularna, M. Bogusławska, Z. Grębecka (red.), Kraków 2010, s. 271-286.

Bogusławska M., Być jak Josip Broz! Komunistyczny projekt dzieciństwa - przypadek jugosłowiański, [w:] Komunistyczni bohaterowie, t. 2: Przemiana, bunt, odrzucenie, M. Bogusławska, Z. Grębecka (red.), Warszawa-Kraków 2012, s. 13-34.

Bogusławska M., Egzotyczni przyjaciele Josipa Broza Tity. O recepcji udziału SFRJ w Ruchu Państw Niezaangażowanych $w$ perspektywie postjugosłowiańskiej, [w:] Komunistyczni bohaterowie, t. 1: Tradycja, kult, rytuat,

88 S. Antolić, Poljaci, [w:] LYUM, s. 316.

89 R. Mazurek, Wakacje w Peerelu, „Sieci” 2013, nr 29 (22-28.07.), s. 43. 
M. Bogusławska, Z. Grębecka, E. Wróblewska-Trochimiuk (red.), Warszawa-Kraków 2011, s. 139-166.

Bogusławska M., Jugonostalgia, [w:] Popkomunizm. Doświadczenie komunizmu a kultura popularna, M. Bogusławska, Z. Grębecka (red.), Kraków 2010, s. 351-353.

Bogusławska M., Tito od kuchni. Popularne (re)konstrukcje obrazu komunistycznej Jugosławii, [w:] Popkomunizm. Doświadczenie komunizmu a kultura popularna, M. Bogusławska, Z. Grębecka (red.), Kraków 2010, s. 251-270. Bošković A., Yugonostalgia and Yugoslav Cultural Memory: Lexicon of Yu Mythology, „Slavic Review. Interdisciplinary Quarterly of Russian, Eurasian, and East European Studies" 2008, no. 1, s. 54-78.

Czapik-Lityńska B., Rozpad Jugosławii jako rozpad wartości. Punkt widzenia Dubravki Ugrešić i Slavenki Drakulić, „Południowosłowiańskie Zeszyty Naukowe" 2007, nr 4, s. 31-42.

Debeljak A., Moje Bałkany: erozja pamięci $i$ wyplywające $z$ niej zagrożenia, „Krasnogruda” 2002-2003, nr 16, s. 9-18.

Dedijer V., Josip Broz Tito - prilozi za biografiju, Beograd 1953.

Dedijer V., Novi prilozi za biografiju Josipa Broza Tita, t. 1-2, Zagreb-Rijeka 1980-1981.

Dragojević R., Ironija kao znak nemoći, „Novosti” 2013, nr 681.

Eckes T., Politische Orientierung und die semantische Struktur politischer Begriffe, ,Zeitschrift für Sozialpsychologie”, 1986, vol. 4, s. 255-269.

Janover M., Nostalgias, „Critical Horizons” 2001, no. 4, s. 111-133.

Jurčević P., 'Leksikon YU mitologije' u Puli, hrvatskom gradu u kojemu je Thompsonu zabrjen nastup, http://www.hrsvijet.net/index.php?option=com_ content\&view_article\&id=18584: leksikon-yu-mitologije-u-puli-hrvatskomgradu-u-kojem-jethompsonu-zabranjen-nastup\&catid=47:kazaliste\&cI temid=162 [dostęp: 13.07.2013].

Kawka M., Płaneta P., Dyskursy o Macedonii, Kraków 2013.

Ko je dobro, a ko loše prošao u Jugoslaviji [rozmowa O. Karabega z M. Dragičević-Šešić i I. Žaniciem, 7.10.2012], http://www.slobodnaevropa.org/ content/most-ko-je-dobro-a-ko-lose-prosao-u-jugoslaviji/24731248.html [dostęp: 13.07.2013].

Kostić S., Cvetković Lj., U traganju za izgubljenim identitetima, „Zarez. Dvotjednik za društvena i kulturna zbivanja” 2004, nr 132.

Kozub K., Politycy z pierwszych stron gazet, Warszawa 1976.

Mazurek R., Wakacje w Peerelu, „Sieci” 2013, nr 29, 22-28.07.

Moroz-Grzelak L., Granice i pamięć jako kategorie południowosłowiańskiej rzeczywistości - kompensacyjne mitotwórstwo, rewizja historii, jugonostalgia, 
[w:] Międzycywilizacyjny dialog w świecie słowiańskim w XX i XXI wieku, I. Stawowy-Kawka (red.), Kraków 2012, s. 22-33.

Pauker I., Reconciliation and Popular Culture: A Promising Development in Former Yugoslavia?, „Local-Global: Identity, Security, Community” 2006, no. 2 , s. $77-82$.

Radak A., Od Adrije pa do žmurke, „Zarez. Dvotjednik za društvena i kulturna zbivanja" 2004, nr 132, s. 13.

Radenković L., Tito jako bohater mityczny, [w:] Komunistyczni bohaterowie, t. 1: Tradycja, kult, rytuał, M. Bogusławska, Z. Grębecka, E. Wróblewska-Trochimiuk (red.), Warszawa-Kraków 2011, s. 125-138.

Rawski T., Josip Broz Tito - charyzmatyczny przywódca? Analiza mitu wodza na przykładzie filmu „Sutjeska”, [w:] Poznać Batkany. Historia - Polityka - Kultura, K. Taczyńska, S. Sochacki, M. Zečević (red.), Toruń 2011, s. 279-292.

Rekść M., Bałkańskie trawestacje mitu pochodzenia, „The Peculiarity of Man” 2010, nr 14, s. 242-262.

Rekść M., Jugonostalgia i titonostalgia. Tęsknota za przeszłościa w wyobrażeniach zbiorowych społeczeństw byłej Jugosławii, [w:] Poznać Bałkany. Historia - polityka - kultura - języki IV, K. Taczyńska, A. Twardowska (red.), Toruń 2012, s. 233-258.

Rekść M., Konsumpcjonizm w wydaniu albańskim, „The Peculiarity of Man” 2012, nr 15, s. 191-205.

Rekść M., Mity narodowe i ich rola w kreowaniu polityki na przykładzie państw byłej Jugosławii, Łódź 2013.

Reykowski J., Poziom politycznego myślenia a rozwiązywanie społecznych zadań koordynacyjnych, „Czasopismo Psychologiczne” 1996, nr 1, s. 7-30.

Sekulić V., Novi prilozi za Leksikon YU mitologje, „Novosti” 2009, nr 519, http://www.novosti.com/2009/11/novi-prilozi-za-leksikon-yu-mitologije/ [dostęp: 5.08.2013].

Sepkowski A., Ideologie w przestrzeni mitycznej, [w:] Mity historyczno-polityczne, wyobrażenia zbiorowe, polityka historyczna. Studia i materiały, t. 2, E. Ponczek, A. Sepkowski (red.), Toruń 2012, s. 10-35.

Simić P., Tito. Zagadka stulecia, Wrocław 2011.

Šipka D., Demokracja a interes narodowy w ujmowaniu sytuacji politycznej: przykład wojny w dawnej Jugosławii, Poznań 2002.

Stanisławski W. (współpraca Konikiewicz A.), Oskarżyciel objazdowy, „Rzeczpospolita” (dodatek „Plus Minus”) 2013, 7-8.12.

Stys H., Dysydenci i opozycja w socjalistycznej Jugosławii 1945-1990. Wybrane zagadnienia, [w:] Poznać Bałkany. Historia - polityka - kultura, K. Taczyńska, S. Sochacki, M. Zečević (red.), Toruń 2011, s. 65-84. 
Stys H., Inna twarz totalitaryzmu. III Plenum KC Związku Komunistów Jugosławii (16-17 stycznia 1954) i odsunięcie Milovana Đilasa od władzy, „Dzieje Najnowsze" 2009, nr 2, s. 57-93.

Stys H., Milovan Đilas o wodzach rewolucji, „Dialog i Polityka” 2008, nr 10, s. $97-113$.

Stys H., Milovan Djilas i Polska - wzajemne inspiracje, [w:] Poznać Bałkany. Historia - polityka - kultura - jezzyki V, K. Taczyńska, A. Twardowska (red.), Toruń 2013, s. 79-105.

Szczepański W., Likwidacja polityczna Aleksandra Rankovicia i jej wplyw na przeobrażenia komunizmu jugosłowiańskiego, [w:] Komunistyczni bohaterowie, t. 2: Przemiana, bunt, odrzucenie, M. Bogusławska, Z. Grębecka (red.), Warszawa-Kraków 2012, s. 195-209.

Tanner M., Chorwaci, [w:] Chorwacja, E. Kosiba (red.), Warszawa 2007.

Ugrešić D., Kultura kłamstwa, Wołowiec 2006.

van Dijk T. A. (red.), Dyskurs jako struktura i proces, Warszawa 2001.

Zalewski J., Tęsknota za mitem możliwościa wypełniania próżni politycznej, [w:] Mity historyczno-polityczne, wyobrażenia zbiorowe, polityka historyczna. Studia i materiaty, t. 3, E. Ponczek, A. Sepkowski, M. Rekść (red.), Toruń 2013, s. 33-43.

Zdański J., Współczesny mit polityczny - forma świadomości społecznej, [w:] Mity historyczno-polityczne, wyobrażenia zbiorowe, polityka historyczna. Studia i materiały, t. 2, E. Ponczek, A. Sepkowski (red.), Toruń 2012, s. 36-43.

Zieliński B., Tito jako antybohater komunistycznego świata, [w:] Komunistyczni bohaterowie, t. 2: Przemiana, bunt, odrzucenie, M. Bogusławska i Z. Grębecka (red.), Warszawa-Kraków 2012, s. 175-193.

http://czarne.com.pl/katalog/autorzy/dubravka-ugresic [dostęp: 13.07.2013].

http://en.wikipedia.org/wiki/ Kaqusha_Jashari [dostęp: 6.08.2013].

http://inanutshell.hr/ [dostęp: 13.07.2013].

http://leksikon-yu-mitologije.net/ [dostęp: 12.07.2013].

www.postscriptum.hr [dostęp: 12.07.2013].

http://postscriptum.hr/leksikon-yu-mitologije [dostęp: 12.07.2013].

http://postyu.info/ [dostęp: 12.07.2013].

http://sr.wikipedia.org/wiki//Пелагија_Белоусова [dostęp: 5.08.2013].

http://www.culturecongress.eu/people/sesic_milena [dostęp: 7.08.2013].

http://www.filmweb.pl/film/Decko+koji+obecava-1981-222253 [dostęp: 6.08.2013].

http://www.youtube.com/leksikonyumitologije [dostęp: 13.07.2013].

https://twitter.com/LeksikonYU [dostęp: 13.07.2013].

https://www.facebook.com/pages/Leksikon-YU-mitologije/2371665397 51167

[dostęp: 13.07.2013].

https://www.google.pl/search?q=Petra+Jur\% [dostęp: 8.08.2013]. 


\begin{abstract}
For some time now Poles seem to be increasingly more interested in the Yugoslav popular culture which has thus been gaining its own experts as well as lovers in Poland. It is undoubtedly associated with the development of studies in fields such as (Southern) Slavonic and Balkan Philology as well as with increasing historical, politological, ethnological and anthropological research into the past and present of the post-Slavic area, including cultural, social and political issues.

Leksikon YU mitologije (The Lexicon of YU mythology), published in 2005 in Serbian (Belgrade) and distributed more widely in Croatia, is a unique work in the field of cataloging and recognizing phenomena of popular culture of Yugoslavia. This impressive book edited by Iris Adrić, Vladimir Arsenijević and Djordje Matić several years after the break-up of the Socialist Federative Republic of Yugoslavia (SFRY) is the result of work of many professional lexicographers and even a larger group of amateur lexicographers representing different nationalities. It is also the realisation of a design of Dubravka Ugrešić, Dejan Kršić and Ivan Molek dating back to 1989, a few years before the fall of SFRY.

The thoughts on some of the content contained in lexicon is to provide not only an opportunity to look at the selected phenomena of popular Yugoslav culture in the communist period. It is also intended as a contribution to reflection and discussion on the relationship of these phenomena with the identity of the Yugoslavs over their current functioning, hence "life after life"), and finally on the determinants of the process of the creation of certain specific images of collective memory, among which one should mention "yugonostalgia", which is one of the most important imperatives of participation of many authors of the lexicon.
\end{abstract}

Keywords: Lexicon of YU mythology, Yugoslavia, popular culture, communism, myths, symbols, memory, yugo-nostalgia 